\title{
Infectious health care workers: should patients be told?
}

Oliver Blatchford, Sarah J O'Brien, Mary Blatchford and Avril Taylor University of Glasgow, Glasgow and Scottish Centre for Infection and Environmental Health, Glasgow

\begin{abstract}
The risk of transmission of HIV or hepatitis B from infectious health care workers to patients is low. However, inadvertent exposure causes great concern amongst patients of an infected health care worker. The patients of a Scottish dentist diagnosed hepatitis $B$ e antigen positive were informed by letter of their exposure. A sample of patients was sent a postal questionnaire. Most (56\%) respondents reported feeling anxious on receiving the letter but almost all (93\%) thought patients should always be informed following treatment by an infectious health care worker, although the risk was very small.

We discuss clinical and ethical factors relating to informing patients following exposure to an infectious health care worker. We suggest that a balance should be struck between patients'wishes to know of risks to which they have been exposed, however small, and the professional view that when risks are negligible, patients need not be informed.
\end{abstract}

(Fournal of Medical Ethics 2000;26:27-33)

Keywords: Disease transmission - professional to patient; health personnel; dentists; patient information; truth disclosure; hepatitis B; HIV

\section{Introduction}

This paper arises from the decision to inform 6,753 patients following their exposure to an infectious health care worker. Should patients be told following such an exposure, even where their risk of infection is low? It can be argued that this may cause unnecessary anxiety, but not informing patients exposes professionals to the charge of paternalism. This paper considers the wishes of patients and discusses the ethics of informing patients.

Risks to patients from HIV and Hepatitis B It was recognised in the early 1970s that patients were at risk of acquiring hepatitis B infection by iatrogenic transmission from an infected health care worker. ${ }^{1}$ Infection may be transmitted by either a chronic carrier of hepatitis B or an asymptomatic health care worker who is incubating the disease. Procedures such as injections, ${ }^{2}$ dental surgery ${ }^{3}$ and general and gynaecological surgery ${ }^{4}$ have all been implicated. There have been at least 12 clusters of hepatitis B infections associated with infected health care workers in England, Wales and Northern Ireland ${ }^{4}$ and at least 20 published reports ${ }^{5}$ of the transmission of hepatitis B from infected health care workers to their patients worldwide. Despite immunisation and screening of health workers, the transmission of hepatitis B from health care workers to patients has been reported recently. ${ }^{67}$

There have been only two reports of transmission of HIV from infected health care workers to their patients. ${ }^{89}$ This is consistent with HIV having both a lower seroprevalence and a lower infectivity than hepatitis B. The risk of transmission of HIV from a clinical care worker is approximately 100 times less than that of hepatitis B. However, the two infections pose a similar overall risk to patients because HIV carries a risk of death approximately 100 times greater than hepatitis B. ${ }^{10}$

Nine clusters of hepatitis B transmission from health care workers involved a total of ten dentists or oral surgeons, all of whom practised in the United States (table 1). One episode of transmission was detected after an episode of acute hepatitis B in a dentist, following which surveillance of his patients proved that transmission had occurred. ${ }^{11}$ The others were discovered in the course of the investigation of a cluster of clinical cases of hepatitis B. Most of these clusters were discovered through routine surveillance operations. One of the dentist-associated clusters had an unexpectedly high case-fatality rate $(22 \%))^{12}$ There were no deaths in the other reported dental clusters. Where the dentist's HBeAg status was determined, it was positive.

Table 1 shows that patients of dentists who are infectious for hepatitis B may be at risk of infection. The wide range in risk estimates probably arises from varying methods of case ascertainment in these investigations. It has been suggested that there may have been other clusters, which were not detected for two reasons. Firstly, 
Table 1 Published reports of dental iatrogenic HBV infection

\begin{tabular}{|c|c|c|c|c|c|c|c|c|}
\hline \multirow[b]{2}{*}{$\begin{array}{l}\text { Year } \mathbb{E} \\
\text { Reference }\end{array}$} & \multirow[b]{2}{*}{ Place } & \multirow[b]{2}{*}{ Dental HCW(s) status } & \multicolumn{2}{|c|}{$\begin{array}{l}\text { Clinical } \\
\text { infections }\end{array}$} & \multicolumn{2}{|c|}{ Lookback exercise } & \multirow[b]{2}{*}{$\begin{array}{l}\text { Procedures } \\
\text { undertaken }\end{array}$} & \multirow[b]{2}{*}{ Comments } \\
\hline & & & $\begin{array}{l}\text { cases } \\
(n)\end{array}$ & rate & $\begin{array}{l}\text { cases } \\
(n)\end{array}$ & rate & & \\
\hline $1972^{11}$ & $\begin{array}{l}\text { Baltimore, } \\
\text { USA. }\end{array}$ & $\begin{array}{l}2 \text { dentists: acutely ill: } \\
\text { HBsAg }+, \text { HBeAg } \\
\text { n.k. }\end{array}$ & 13 & * & $\dagger$ & & $\begin{array}{l}\text { General } \\
\text { dentistry. }\end{array}$ & $\begin{array}{l}\text { No gloves, cut hands once or } \\
\text { twice per month. }\end{array}$ \\
\hline $1976^{28}$ & $\begin{array}{l}\text { Los Angeles, } \\
\text { USA. }\end{array}$ & $\begin{array}{l}\text { Chronic carrier, } \\
\text { HBsAg }+, \text { HBeAg }+.\end{array}$ & 3 & * & 43 & * & $\begin{array}{l}\text { General } \\
\text { dentistry. }\end{array}$ & $\begin{array}{l}\text { Resumed practice wearing gloves. } \\
\text { One further case. Barred from } \\
\text { practice thereafter. }\end{array}$ \\
\hline $1977^{29}$ & $\begin{array}{l}\text { Pennsylvania, } \\
\text { USA. }\end{array}$ & $\begin{array}{l}\text { Chronic carrier, } \\
\mathrm{HBsAg}+, \mathrm{HBeAg}+.\end{array}$ & 55 & $1: 400$ & $t$ & & Extractions. & $\begin{array}{l}\text { Probable transmission from cuts } \\
\text { on fingers. Resumed practice after } \\
\text { HBcAb developed, wearing } \\
\text { gloves. No further cases identified }\end{array}$ \\
\hline $1978^{30}$ & $\begin{array}{l}\text { Baltimore, } \\
\text { USA. }\end{array}$ & $\begin{array}{l}\text { Acute illness, } \\
\text { HBsAg }+, \mathrm{HBeAg}+\end{array}$ & 3 & * & 6 & $1: 66$ & $\begin{array}{l}\text { Extractions } \\
\text { and dental } \\
\text { surgery. }\end{array}$ & $\begin{array}{l}\text { Resumed practice while } \mathrm{HBeAg} \\
\text { positive, wearing gloves. No } \\
\text { further cases identified. }\end{array}$ \\
\hline $1979^{31}$ & $\begin{array}{l}\text { Connecticut, } \\
\text { USA. }\end{array}$ & $\begin{array}{l}\text { Acute illness, } \\
\mathrm{HBsAg}+, \mathrm{HBeAg}+\text {. }\end{array}$ & 12 & $\begin{array}{l}3 \% \text { to } \\
11 \%\end{array}$ & 38 & $\begin{array}{l}6.7 \% \text { to } \\
31 \%\end{array}$ & $\begin{array}{l}>80 \% \\
\text { extractions. }\end{array}$ & $\begin{array}{l}\text { Dentist had eczema of hands and } \\
\text { did not wear gloves. Attack rates } \\
\text { varied with time. Left practice. }\end{array}$ \\
\hline $1980^{32}$ & Atlanta, USA. & $\begin{array}{l}\text { Chronic carrier, } \\
\text { HBsAg }+, \text { HBeAg }+ \text {. }\end{array}$ & 3 & * & 10 & $1.8 \%$ & Not stated. & Resumed practice, wearing gloves. \\
\hline $1983^{33}$ & $\begin{array}{l}\text { Washington } \\
\text { state, USA. }\end{array}$ & $\begin{array}{l}\text { Chronic carrier, } \\
\mathrm{HBsAg}+, \mathrm{HBeAg}+\end{array}$ & 4 & $0.11 \%$ & $7 \ddagger$ & * & $\begin{array}{l}\text { General } \\
\text { dentistry. }\end{array}$ & $\begin{array}{l}\text { Resumed practice while a carrier, } \\
\text { wearing gloves. No further cases } \\
\text { identified. }\end{array}$ \\
\hline $1985^{12}$ & $\begin{array}{l}\text { Indiana, } \\
\text { USA. }\end{array}$ & $\begin{array}{l}\text { Chronic carrier, } \\
\mathrm{HBsAg}+, \mathrm{HBeAg}+\end{array}$ & $\begin{array}{l}9(2 \\
\text { died })\end{array}$ & * & 24 & $3.2 \%$ & $\begin{array}{l}\text { General } \\
\text { dentistry. }\end{array}$ & $\begin{array}{l}\text { "Obsessive hand scrubber", no } \\
\text { gloves used. Dentist had had } \\
\text { HBV vaccination. }\end{array}$ \\
\hline $1986^{34}$ & $\begin{array}{l}\text { New } \\
\text { Hampshire, } \\
\text { USA. }\end{array}$ & $\begin{array}{l}\text { Chronic carrier, } \\
\mathrm{HBsAg}+, \mathrm{HBeAg}+\text {. }\end{array}$ & 4 & * & $\dagger$ & & $\begin{array}{l}\text { Multiple } \\
\text { Extractions }\end{array}$ & $\begin{array}{l}\text { Did not wear gloves but scrubbed } \\
\text { hands between cases. }\end{array}$ \\
\hline
\end{tabular}

^Not estimated.

†No lookback / case finding exercise or serological survey undertaken.

$\ddagger 3$ clinical cases discovered by matching reported clinical hepatitis cases to dentist’s patient list plus 4 original cases.

in approximately $70 \%$ of cases, hepatitis B infection is not clinically evident, which reduces the probability of cluster identification through routine surveillance. Secondly, the long incubation period of hepatitis B may make the identification of a common source difficult. ${ }^{11}{ }^{13}$

\section{The incident}

In May 1995 a dentist practising in central Scotland was discovered to be hepatitis $\mathrm{B}$ e antigen seropositive and therefore highly infectious. The dentist ceased clinical practice immediately and an incident team was convened.

The 6,753 patients treated by the dentist during his professional career were identified and crossmatched with the records of notifications and laboratory diagnoses of hepatitis B since 1988. No patients were shown to have developed clinical hepatitis B subsequent to treatment by the dentist.

The incident group then debated whether there should be any further action. One view expressed was that since routine data sources had identified no clinical cases of hepatitis B amongst the dentist's patients, the probability of undetected transmission was very low. A "look back" exercise notifying the dentist's former patients would therefore cause them unnecessary anxiety with lit- tle health benefit. The contrasting view was that patients had the right to know that they had been inadvertently exposed to a risk, however low. This would allow asymptomatic carriers to be identified and offered treatment.

Some members of the incident team felt that while the public might be concerned about HIV, there was no public anxiety about hepatitis B and it was therefore less important to inform patients. The contrasting view was that the Scottish public was very concerned about hepatitis B because of its association with injecting drug users.

The directors of public health of the relevant health boards, in consultation with the incident team, decided it was their duty to notify these patients of their exposure. It was decided that the only practical way to contact such a large number $(6,753)$ of patients was to write to them directly (see annex). This was done despite a recent English High Court ruling that two English health authorities, in notifying patients by letter, had failed to exercise due care when informing a smaller group of patients treated by an HIVpositive surgeon. ${ }^{14}$

Following despatch of the letters, a large number $(3,289)$ of telephone calls were received on dedicated telephone helplines and at health 
Table 2 Patient responses to incident

\begin{tabular}{|c|c|c|c|c|c|}
\hline Question & $\begin{array}{l}\text { Question } \\
\text { number }\end{array}$ & $\begin{array}{l}\text { Yes } \\
n(\%)\end{array}$ & $\begin{array}{l}\text { No } \\
n(\%)\end{array}$ & $\begin{array}{l}\text { Unsure } \\
n(\%)\end{array}$ & $\begin{array}{l}\text { Total } \\
n\end{array}$ \\
\hline Did you receive the letter? & q2 & $288(99 \%)$ & $2(1 \%)$ & $0(0 \%)$ & 290 \\
\hline Did you understand the letter? & q3 & $273(97 \%)$ & $6(2 \%)$ & $2(1 \%)$ & 281 \\
\hline Did the letter contain sufficient information? & q5 & $173(60 \%)$ & $86(30 \%)$ & $27(9 \%)$ & 286 \\
\hline Did you contact the helpline? & g8 8 & $123(43 \%)$ & $161(55 \%)$ & $1(0 \%)$ & 285 \\
\hline Did you get sufficient information from the helpline? & $\mathrm{q} 12$ & $68(59 \%)$ & $43(37 \%)$ & $4(3 \%)$ & 115 \\
\hline Did you have a blood test? & g15 & $56(20 \%)$ & $228(79 \%)$ & $3(1 \%)$ & 287 \\
\hline
\end{tabular}

boards from patients and their relatives. They sought more information about the incident, the dentist, hepatitis B and their levels of risk. Following counselling, 493 patients had blood tests for hepatitis B. All proved negative.

The incident group decided that a survey of patients' attitudes to the incident should be undertaken to inform the management of similar incidents in the future.

\section{The survey}

Following ethical committee approval, a piloted anonymous postal questionnaire (appendix) was distributed to a ten per cent random sample of patients (528) in three of the four health board areas. Responses to open-ended questions were analysed by classifying the themes they raised using a specially designed computer database. This classification was reviewed by an independent coder.

A single mailing resulted in 291 responses $(55 \%)$. The original letter had been received by $99 \%$ of respondents; it was understood by $97 \%$. Sixty per cent of respondents believed the letter contained sufficient information while $30 \%$ thought it did not (table 2). Most (54\%) respondents reported feeling slightly or very anxious upon receiving the letter. The helpline was contacted by those patients reporting greater anxiety levels $(\mathrm{p}<0.00001)$. Following contact with the helpline, $57 \%$ of respondents were reassured. Of the 46 respondents who had blood tests, only one remained anxious following a negative result (table 3).

Almost all respondents (93\%) felt that patients should always be informed if they have been treated by an infectious health care worker, even if

Table 3 Responses regarding anxiety level

\begin{tabular}{lccc}
\hline Question & $\begin{array}{l}\text { After letter } \\
n(\%)\end{array}$ & $\begin{array}{l}\text { After helpline } \\
n(\%)\end{array}$ & $\begin{array}{l}\text { After test } \\
n(\%)\end{array}$ \\
\hline Question number & $\mathrm{q} 4$ & $\mathrm{q} 11$ & $\mathrm{q} 16$ \\
Completely reassured & $51(18 \%)$ & $26(23 \%)$ & $39(85 \%)$ \\
Slightly reassured & $49(17 \%)$ & $39(34 \%)$ & $6(13 \%)$ \\
Unchanged & $23(8 \%)$ & $28(24 \%)$ & $0(0 \%)$ \\
Slightly anxious & $116(41 \%)$ & $14(12 \%)$ & $1(2 \%)$ \\
Very anxious & $44(15 \%)$ & $7(6 \%)$ & $0(0 \%)$ \\
Can't remember & $3(1 \%)$ & $1(1 \%)$ & $0(0 \%)$ \\
Total & 286 & 115 & 46 \\
\hline
\end{tabular}

the risk was very small. Three per cent were unsure, three per cent felt they should sometimes be informed and a single respondent believed they should never be informed. Most (61\%) felt they should be informed by letter but $29 \%$ preferred to be informed in person. Respondents were equally divided between being informed by their own general practitioner, or a representative of the health board or hospital.

The commonest themes of the responses to open-ended questions were a need for more information on hepatitis B, a desire to know the dentist's identity, and comments on the availability of the telephone helpline. Other topics raised included the suggestion that all medical staff should have regular screening for HIV and hepatitis $B$, that all patient contacts of the dentist should have had a screening blood test, and that the original letter informing them of their contact was impersonal, patronising or unhelpful.

\section{Discussion: should patients be informed?} REASONS FOR INFORMING PATIENTS

There is no consensus on whether to inform patients of an infected health care worker of their risk, even when the infection is recognised and the infected health care worker continues to be allowed to practise. The American Medical Association has issued guidance that HIV-infected practitioners undertaking exposure-prone procedures must either disclose this to their patients, obtaining their informed consent prior to treatment or must withdraw from treatment. ${ }^{15}{ }^{16}$ The New York State Department of Health issued contradictory guidance which did not require disclosure because of the very low risk of transmission of HIV. Similar statements have been made by other American medical authorities. ${ }^{17}$

In the United Kingdom health care workers who are known to be seropositive for HIV or hepatitis B e antigen may not undertake exposure prone procedures ${ }^{13} 18$ thus protecting patients from known infection risks. Canada's Laboratory Centre for Disease Control has questioned the value of categorising procedures as exposureprone in the absence of procedure-specific risk data and does not require health care workers to disclose their infective status. ${ }^{19}$ 
The decision to inform patients retrospectively of their risk from an infected health care worker is even more contentious. The United Kingdom's Department of Health's guidance obliges health authorities to inform all patients who may have been at risk of infection by health care workers subsequently diagnosed HIV-positive. ${ }^{20}$ This has been supported by the argument that patients have the right to know that they have been treated by an infectious health care worker and that this right overrides professionals' need for secrecy. ${ }^{21}$ However, the UK Department of Health's advice has been challenged on the ground that the risk to patients from an infectious professional is extremely small. ${ }^{22}$

Despite the similarity of the overall risk to patients from HIV and hepatitis $\mathrm{B},{ }^{10} \mathrm{UK}$ guidance is less explicit as to whether patients should be informed following risk exposure to hepatitis B in a health care setting. ${ }^{13}$

American recommendations for retrospective patient notification exercises (also known as "look back programmes") have been produced by the Association for Practitioners in Infection Control (APIC) for use in cases where a health care worker is discovered to be HIV- or hepatitis B-infectious. ${ }^{23}$ They state that such an exercise may have three purposes:

1. It may enable patients infected by disease transmitted from the health care worker to be identified.

2. Exposed patients may be offered a prophylactic medical intervention to reduce their risk of subsequently developing the disease.

3. Epidemiological studies to define the risk of transmission of disease from health care workers to patients may be undertaken.

The first and second of the APIC purposes are intended for the clinical benefit of patient contacts of the health care worker as it is implied that the offer of appropriate treatment would result from positive case-finding. The last of the APIC purposes however, is for research and therefore should be considered in the context of the Helsinki declaration. ${ }^{24}$

The APIC statement ${ }^{23}$ describes only clinical reasons for embarking upon a look back exercise. It does not consider that it might be justified to allay public fears or patients' anxieties. It appears to be informed only by professionals. ${ }^{25}$ It does not consider patients' rights; whilst American patients have the right to know if they are being treated by an infected health care worker, ${ }^{15}{ }^{16}$ they apparently lose this right if the information becomes available only after their treatment. ${ }^{23}$

Should the decision on whether to inform patients retrospectively be left to doctors, or should the patients' views be held to be important? Traditionally, doctors made decisions on their patients' behalf, but it is increasingly recognised that ethical dilemmas might best be resolved by wider discussion with patients and the public.

This study showed that the views of the patients differed quite markedly from the opinion of many of the professionals involved. It strikingly demonstrated that patients do wish to have information about a risk to which they had inadvertently been exposed in the health care setting, even though that risk was very small. Despite the anxiety caused by knowledge of their exposure, they believed that the letter informing them in the first instance should have contained more detailed information. Greater knowledge might have provided better reassurance.

\section{Screening for transmission}

The Wilson and Jungner criteria for a screening programme ${ }^{26}$ provide a useful framework for consideration of the value of a look back exercise in the first two APIC reasons for notification programmes.

1. Is the disease an important health problem for the individual and the community? Clearly, both HIV and hepatitis B are significant illnesses for both individuals and communities.

2. Is there an accepted treatment which confers benefit? Treatments for HIV and hepatitis B have satisfied licensing procedures for evidence of effectiveness. These interventions may reduce the risk of transmission of infection following exposure. Appropriate treatment also reduces the long term consequences of these infections. Furthermore, a negative blood test itself may provide reassurance and reduction in anxiety levels and could also be considered to be a treatment.

3. Are facilities for diagnosis and treatment available? Both illnesses may be relatively easily diagnosed whilst asymptomatic. Treatments are available in most parts of the developed world.

4. Is there a recognisable latent or early symptomatic phase? Both HIV and Hepatitis B have early latent stages and may have later, often asymptomatic, chronic stages of infection.

5. Is there a suitable test or examination? Serological testing for HIV and hepatitis B is widely available.

6. Is the test acceptable to the population? Appropriate counselling should ensure this.

7. Is the natural history of the condition from its latent phase through to the declared disease understood? The natural histories of both conditions are 
known (including the possibility of lifelong asymptomatic carriage of hepatitis B).

8. Is there an agreed policy on whom to treat as patients? This too would have to be considered for each exercise, although it should only arise as an issue for those exercises satisfying the second APIC purpose, reducing the risk of transmission of disease following risk exposure.

9. Has the cost of the programme been considered in the context of other demands for resources? This would have to be examined for each look back exercise.

A criterion commonly added to those of Wilson and Jungner is:

10. Is the treatment acceptable to both patients and clinicians? For these illnesses, it might be reasonable to expect an affirmative response. Again, this should be ascertained during counselling.

\section{Patients' rights to information}

Does fully informed consent imply that patients have the right to information discovered retrospectively? While informed consent may have been obtained at the time of treatment, is the subsequent emergence of additional information about the treatment relevant? A counterargument to informing patients after inadvertent exposure to HIV or hepatitis B is that they cannot change their decision and withdraw consent to treatment already completed.

Obtaining fully informed consent is morally necessary in order to acknowledge and respect an individual patient's autonomy. Truth disclosure is an integral part of this acknowledgement. Accusations of paternalism may arise from decisions to restrict information to patients.

Look back exercises may be costly and timeconsuming and may erode confidence in the caring professions. However, failure to disclose might be regarded as a cover-up, especially where anxiety is caused after unplanned media disclosure.

The caring professions require patients' trust in order to deliver care effectively. Being seen to foster a culture of openness may enhance patients' trust in the professions while the appearance of concealment would certainly diminish it. In a society with an increasing culture of openness, and where the right to information from governments and official bodies is receiving attention, it would seem desirable to provide comprehensive information about risks.

Patients have a right not to be harmed by their medical practitioner. This right is enshrined in the concept of non-maleficence. Whilst it is the duty of a doctor to do good to patients (benevolence), a particular treatment may not help all individuals. Thus, the least that a doctor should do is to do no harm. ${ }^{25}$ This duty is stated clearly in the Oath of Hippocrates and in the codes of professional conduct of the General Medical Council (GMC), the General Dental Council (GDC) and the United Kingdom Central College for Nursing, Midwifery and Health Visiting (UKCC). By not informing patients of their exposure, transmission might not be recognised, thus patients would be harmed by the denial of appropriate treatment. Moreover, if patients are infected, they constitute a transmission risk to those around them.

\section{Conclusion}

Health carers should not adopt the paternalistic approach of deciding for their patients what level of risk is acceptable, but should consider patients' views. Autonomy and truth disclosure are important influences on this decision. In deciding whether to inform patients, a balance must be struck between their desires to know of past exposure to risks, and the professional view that when risks are negligible, patients need not be informed. This study strongly suggests that patients' needs should be given greater weight. This principle should apply to other types of iatrogenic risk exposure, for example, when Creutzfeldt-Jakob Disease (CJD) is diagnosed following organ transplantation or blood transfusion. ${ }^{27}$

\section{Annex \\ STRICTLY PRIVATE AND CONFIDEN-} TIAL

2 June 1995

«Title» «Forename» «Surname»

"PAdd1"

«PAdd2»

«PAdd3» «PCode»

Our reference: hbv_pat.«CaseNo»

Dear «Title» «Surname»,

We have recently been informed that a dentist who has worked within the Health Board area has been diagnosed as a carrier of the hepatitis B virus. Our records show that you might have seen this dentist. We would like to reassure you that we have no evidence that anyone has been infected in this case but, because we believe that it is good practice to inform relevant patients about such matters, we have sent you this letter.

This risk to patients from a dentist infected with the hepatitis B virus is extremely small. Indeed there are no known cases of a dentist having infected any of his or her patients with hepatitis B in the United Kingdom. 
Hepatitis B is a viral infection which occurs worldwide. The virus is usually spread by blood to blood contact. Hepatitis B rarely causes any serious long-term illness in people who might have become infected.

If you would like any further information we have set up a national free helpline service on: $0800 \times x \times x \times x$ for information and advice.

To be sure that we know you have received this letter, we should be grateful if you would complete the attached slip and return it in the enclosed reply paid envelope.

Yours faithfully

Director of Public Health

I confirm that I have received a letter from the Greater Glasgow Health Board about the dentist carrying the Hepatitis $B$ virus.

Signed: .............................Date:

Name:

Address:

\section{«CaseNo»}

\section{Appendix: Patient questionnaire STRICTLY CONFIDENTIAL Patients' Questionnaire - Hepatitis B health care worker}

How did you first hear about the Dentist with hepatitis B? please 1. tick one box

- Press/TV

- Letter from Health Board

- Neighbours/Family

- Your own doctor

- I can't remember

- Other (please specify:)

2. Did you receive a letter from your Health Board about the Dentist with hepatitis B? please tick one box

- Yes $\bullet$ No I can't

$$
\text { remember }
$$

If you did not receive a letter, please go to question 8.

3. Did you understand that letter? please tick one box

- Yes $\bullet$ No $\quad$ I I can't

4. How did you feel after reading that letter? please tick one box - Completely reassured

- Slightly reassured

- Same as before

- Slightly anxious

- Very anxious

- I can't remember

5. Did that letter contain enough information? please tick one box
- Yes $\bullet$ No
$\begin{aligned} & \bullet \text { I can't } \\ & \text { remember }\end{aligned}$
6. If you do not feel that the letter contained enough
information, what other information should have been
included in the letter? apply

- The Freefone number on the letter - The Health Board's help line

- I can't remember

10. Why did you phone the help line? please tick the boxes that apply

- I was anxious

- I wanted more information

- I wanted to know more about hepatitis B

- I wanted to know about hepatitis B tests

- I wanted to know who the dentist was

- I wanted to be sure that I had been in

contact with the dentist

- I can't remember

- Other (please state:)

11. How did you feel after your phone call? please tick one box

- Completely reassured

- Slightly reassured

- Same as before

- Slightly anxious

- Very anxious

- I can't remember

12. Did you get enough information from your phone call? please tick one box

- Yes $\bullet$ No $\quad$ I can't

remember

13. If you did not get enough information from that call, what other information would you like to have been given?

14. Do you have any other comments about the help line?

15. Did you (Parents: your child) have a blood test for hepatitis B? please tick one box

$$
\text { - Yes } \bullet \text { No } \text { I can't }
$$

remember

16. If you (Parents: your child) did have a blood test, how did you feel after getting your (child's) test result? please tick one box - Completely reassured

- Slightly reassured

- Same as before

- Slightly anxious

- Very anxious

- I can't remember

17. Do you have any other comments about the incident?

Finally, we should be grateful if you would help us by answering some general questions.

18. Do you think that patients who have been treated by somebody with hepatitis B should be informed of this? please tick one box

- Yes - always

- Sometimes

- No - never

- I am not sure

19. If you do think that patients should be informed, what is the best way to inform them? please tick one box

- Letter

- Phone call

- Face to face contact 


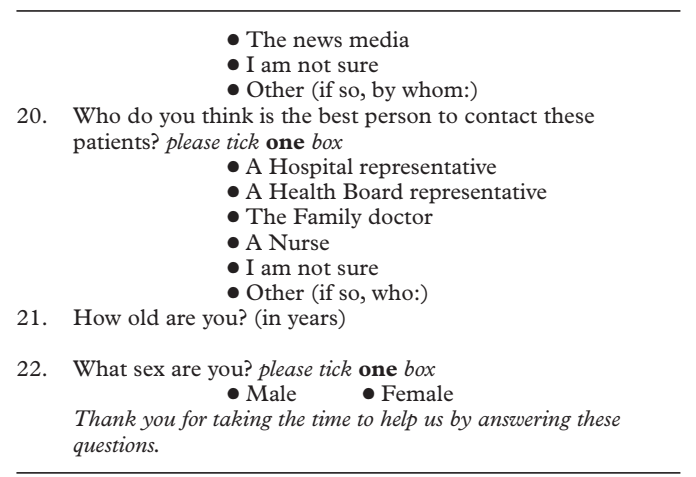

\section{Acknowledgements}

The incident evaluation team comprised Drs Syed Ahmed, Oliver Blatchford, Rob Brogan, John Logan, Sarah J O’Brien, Andrew Riley and Avril Taylor.

We thank the patients who completed the questionnaires and the dentist for personal insights.

Oliver Blatchford is a Research Fellow in the Department of Public Health, University of Glasgow, Glasgow. Sarah f O'Brien is a Consultant Epidemiologist at the Scottish Centre for Infection and Environmental Health, Glasgow. Mary Blatchford is a Senior Tutor in the Department of General Practice, University of Glasgow, Glasgow and Avril Taylor is a Medical Sociologist at the Scottish Centre for Infection and Environmental Health, Glasgow.

\section{References}

1 Grob PJ, Bischof B, Naeff F. Cluster of hepatitis B transmitted by a physician. Lancet $1981 ; 2: 1218-20$.

2 Garribaldi RA, Rasmussen CM, Holmes AW, Gregg MB Hospital-acquired serum hepatitis: report of an outbreak. Fournal of the American Medical Association 1972;19:1577-80.

3 Kane MA, Lettau LA. Transmission of HBV from dental personnel to patients. Fournal of the American Dental Association 1985;110:634 - 6

4 Heptonstall J. Outbreaks of hepatitis B virus infection associated with infected surgical staff. Communicable Disease Report Review 1991;8:R81-4

5 Doebbeling BN, Wenzel RP. Nosocomial viral hepatitis and infections transmitted by blood and blood products. In Mandell GL, Bennett JE, Dolin R, eds. Principles and practice of infectious diseases [4th ed]. New York. Churchill Livingstone, 1995: ch 284 .

6 Anonymous. Possible transmission of hepatitis B from a health care worker to a patient. Communicable Disease Report Weekly 1996;6,33:283.

7 The incident control team and others. Lessons from two linked clusters of acute hepatitis B in cardiothoracic patients. Communicable Disease Report Review 1996;6,9:R119-25.

8 Anonymous. Possible transmission of human immunodeficiency virus to a patient during an invasive dental deficiency virus to a patient during an invasive dental

9 Anonymous. Transmission of HIV from an infected surgeon to a patient in France. Communicable Disease Report Weekly 1997; $7,4: 17$.
10 Webber DJ, Hoffmann KK, Kutala WA. Management of the healthcare worker infected with human immunodeficiency virus: lessons from nosocomial transmission of hepatitis B virus. Infection Control and Hospital Epidemiology 1991;12,10: 625-30.

11 Levin ML, Maddrey WC, Wands JR, et al. Hepatitis B transmission by dentists. Fournal of the American Medical Association 1974;228:1139-40.

12 Shaw FE Jr, Barrett CL, Hamm R, et al. Lethal outbreak of hepatitis B in a dental practice. Fournal of the American Medical Association 1986;255:3260 - 4 .

13 The United Kingdom Advisory Group on Hepatitis. Protecting health care workers and patients from hepatitis $B$. London: HMSO Health Publications Unit, 1993.

$14 \mathrm{~A}$ and $\mathrm{B}$ and others $\mathrm{v}$ Tameside and Glossop and Salford and Trafford Health Authorities. Crown Court, Manchester, Mr Justice French, 1995 Jan 31.

15 Daniels N. HIV infected health care professionals: public threat or public sacrifice? Milbank Quarterly 1992;70,1:3-42.

16 Glantz LH, Mariner WK, Annas GJ. Risky business: setting public health policy for HIV-infected health care professionals. Milbank Quarterly 1992;70,1:43-79.

17 Lieberman KC, Derse AR. HIV-positive health care workers and the obligation to disclose: do patients have a right to know? fournal of Legal Medicine 1991;13:333-56.

18 UK Departments of Health. AIDS-HIV infected health care workers: guidance on the management of infected health care workers. Edinburgh: Scottish Office Home and Health Department, 1993. (AGA00205.043)

19 Anonymous. Blood borne pathogens in the health care setting. Risk for transmission. Canadian Dental Association fournal 1993; 59,A:363-70.

20 The United Kingdom Expert Advisory Group on AIDS. AIDS - HIV infected health care workers: practical advice on notifying patients. Edinburgh: Scottish Office Home and Health Departpatients. Edinburgh: Scottish Offic

21 Dickenson $\mathrm{D}$. The right to know and the right to privacy: confidentiality, HIV and health care professionals. Nursing Ethics 1994;1,2:111-5.

22 Swinhoe C. Commentary: the government has mismanaged cases of HIV infected health care workers. British Medical fournal 1996;312:1152-3.

23 APIC Bloodborne Pathogens Committee. The APIC statement on purposes for and elements of patient notification programs related to the health care worker infected with the human immunodeficiency virus or the hepatitis B "e" antigen. American fournal of Infection Control 1991;19,6:30A-3A.

24 Anonymous. World Medical Association declaration of Helsinki. Recommendations guiding physicians in biomedical research involving human subjects. Fournal of the American research involving human subjects.
Medical Association 1997;277:922-3.

25 Downie RS, Calman KC. Healthy respect. Oxford: Oxford University Press, 1994

26 Wilson JMG, Jungner G. The principles and practice of screening for disease. Public health papers, 34. Geneva: World Health Organization, 1968

27 Christie B. Inquiry ordered after organ donor found to have CJD [news]. British Medical fournal 1997;315:1485.

28 Goodwin D, Fannin SL, McCracken BB. An oral surgeonrelated hepatitis B outbreak. Californian Morbidity 1976;14:1.

29 Rimland D, Parkin WE, Miller GB, et al. Hepatitis B outbreak traced to an oral surgeon. New England fournal of Medicine 1977;296:953-8

30 Hadler SC, Sorley DL, Acree KH, et al. An outbreak of hepatitis $\mathrm{B}$ in a dental practice. Annals of Internal Medicine 1981;95:133-8

31 Reingold AL, Kane MA, Murphy BL, et al. Transmission of hepatitis B by an oral surgeon. Fournal of Infectious Diseases 1982;145:262-8.

32 Goodman RA, Ahtone JL, Finton RJ. Hepatitis B transmission from dental personnel to patients: unfinished business. Annals of Internal Medicine 1982;96:119.

33 Ahtone J, Goodman RA. Hepatitis B and dental personnel: transmission to patients and prevention issues. Fournal of the transmission to patients and prevention issues

34 Centers for Disease Control and Prevention. Outbreak of hepatitis B associated with an oral surgeon in New Hampshire. Morbidity Mortality Weekly Report 1987;36:132-3. 